\title{
Reduction, replacement and ethics of animal use in bio-science research and education
}

\author{
Nisha Aynikkattil Ravindran ${ }^{1}$, Shadiya Pullikkunnummal ${ }^{1}$, Beegam \\ Farhana Fathima Manzil ${ }^{1}$, Megha Kelenchery Ganesh ${ }^{1}$, Srinidhi \\ Yelawahalli Ramappa ${ }^{1}$, Shakeeb Ullah ${ }^{2}$, Asif Javaid ${ }^{2}$, Kamran Safdar ${ }^{2}$ \\ and Muhammad Shuaib Khan ${ }^{2 *}$ \\ 1. Department of Veterinary Pharmacology and Toxicology, College of Veterinary and Animal Sciences, Pookode, \\ Wayanad, Kerala, 673576-India \\ 2. Faculty of Veterinary and Animal Sciences, Gomal University, D.I. Khan-Pakistan \\ *Corresponding author's email: shoaibbaloch2002@yahoo.com
}

Citation

Nisha Aynikkattil Ravindran, Shadiya Pullikkunnummal, Beegam Farhana Fathima Manzil, Megha Kelenchery Ganesh, Srinidhi Yelawahalli Ramappa, Shakeeb Ullah, Asif Javaid, Kamran Safdar and Muhammad Shuaib Khan. Reduction, replacement and ethics of animal use in bio-science research and education. Pure and Applied Biology. Vol. 6, Issue 4, pp1450-1456. http://dx.doi.org/10.19045/bspab.2017.600156

\begin{tabular}{llll}
\hline \hline Received: 30/08/2017 & Revised: 09/11/2017 & Accepted: 22/11/2017 & Online First: 30/11/2017 \\
\hline \hline
\end{tabular}

\section{Abstract}

There is a widespread agreement to lower the quantity of animals used in the scientific research and education. Fewer animals should be used in the scientific and educational research practices. Major alternative to in-vivo trails are the encouragement in the use of in-vitro techniques. In late 1950,s it was proposed to decrease the number of animals in in-vivo studies. Efforts should be made to decrease and substitute them with non-sentimental alternatives. The public concerns about animal use, and ethical issues in scientific trails were seen due to the increased use of animal models in scientific research and education. The learning goals of these laboratory works need careful considerations which may lead to an idea of using the alternative methods in research. It will also help to standardise the use of animals in the in vivo experimentation. In this review the overall types of alternatives and standardization in the use of animals in scientific research and education are discussed.

Keywords: Animal-Ethics; Animal Model; Bio-Science; Alternatives

Introduction

In scientific research and education and training, millions of laboratory animals are used in the name of knowledge acquisition or skill development in the basic life science and professional education. Demands for some animals increased to an extent, but such animals are no longer to exist in the environment for longer period. Despite the availability of alternative methods, even now animals are being used in research and education [1]. It seems still the animals are required in order to fulfill the goals of learning. Learning objectives which are given by their teachers for laboratory classes using animals include skilled practicing including generic skills, hands on animal handling skills and dissection skills. Obtaining innovative and 
existing accurate information needs scientific learning and practicing skills accompanied with communication skills are developing responsible attitudes towards animal experimentation $[2,3]$.

Several alternates to animal use in scientific research and education and were developed in Europe and USA. These include the mannequins, simulators, virtual setting, human volunteers, self-experimentation etc. $[4,5]$. "Alternatives" not only reduce the exposure to animal models, but outcomes are much better.3R's principles i.e. (replacement of animal models, reduction in the quantities of used experimental animals in the scientific research, and improvement of animal model use towards refinement) in the use of animals in experimentation [6, 7]. Method of refinement are established to the most basic possible end point by using the most suitable analgesics and anesthetics for involved painful practice also usage of the most suitable handling techniques to the animal model [8]. Need of sufficient training prior to performing experiment should be ensured and appropriate drug dosages according to their body weights and should not expired, performance of surgeries and other related procedures should be done aseptically to prevent the infection. Techniques of reduction should accomplish in preliminary studies and experimental design should use animals as their own control. Collect the data for more than one experiment simultaneously; refer to the stabilization and use of minimum number of animals to minimize the variables and treatment groups such as disease, diet, dose rates, stress and genetics [9]. Replacement methods are the replacement of insentient materials in the place of conscious higher animals could be selective as absolute to replace the higher animals with lower animals, replacement of live animals with the dummies for the teaching and dissecting purpose, use of computer stimulation and in vitro methods i.e. use cell and tissue culture $[\mathbf{1 0}, \mathbf{1 1}]$.

\section{Substitutions in scientific research and education}

In scientific research and education substitutions is the term normally means replacement or substitution i.e. it is mainly done by use of non-animal methods. Use of non-animal models is also help to decrease the quantity of animals used for the training and experimental procedure $[12,13]$. Varieties of alternatives are 3D-animated models, dummies and mechanical types of simulators, computer based simulation and virtual-aids, self-experimentation and volunteering anthropological studies, use of plant in scientific experimentations, observational and field studies, tissues and organs from slaughter house and fisheries and fish culture, In vitro studies on cell lines, tissue culture, animal cadavers from naturally died and euthanized animals, clinical trials and practices. The full picture to use other possibility approaches in scientific teaching and research are divided into three groups they are more ethical, didactical and more economical to use [14, 15].

Nowadays animal use in research and education is being reduced, but only in necessary should we allow animal use in the classroom. Major disadvantage of animals use in scientific trainings is that mishandlings with animals will develop undesirable effects on students. These types of trainings do not enhance the proper attitude building of teen ager students towards the animal ethics i.e. the animals be worthy of appreciation, respect and fundamental values. Non-animals model may be developed not only for ethical reasons but for primarily for didactic reasons. Animal use in research and education is costly and looking after of animals is highly expensive due to expenditure like housing, laborers and management of animals and more number of working people and time management is requisite to supervise and startup of animal model experimentation $[16,18]$. 
Some educational alternatives are expensive to purchase, than animals but they can be used repeatedly overtime, so we can save money in the long run. Advantages of alternative methods are reusable and can be used another time without any difficulty. Instead of a the specific animals can offer precise and comprehensive time period that avoids the negative learning, feedback and know-how of the modern audio-visual technique which can used as alternative method of modern scientific research and education which offer the possibility to reveal the phenomenon that not normally can't be observed in animal experiments as like animations of organs and cell functions etc. Computerized and information technology assisted and aided learning can regulate many education and scientific objectives and increases the students and staff interaction with the people abroad. It also lowers the cost and makes it more reliable methods and also the student has a positive response about the use of computer assisted learning $[19,20]$.

Sources of alternatives to reduce animal use in scientific trainings and presentation are assistance of the other trainers who can object to the contributing in animal experimentation and discover their own alternate workouts, by developing alternate techniques either alone or with others inside or outside the organization. Symposiums, scientific-fairs, educational assistances and resources, online helps, outreach programs from various institutional and organizational sources and their relevant information sources are the somewhat substitutions of animal models in the scientific education. The following organizations support the use of alternatives in research and education. The organizations like European resources centers for alternatives in higher education (EURCA), the intentional networks for humane research and education- Inter NICHE and NORINA Database use the audiovisual alternative to the animals in teaching $[3,21]$.

\section{In-vitro techniques}

In vitro technique is given procedure doing with the help of microorganisms' cells and other biological material under the controlled environment outside killing organisms. In vitro studies are able to replacing the animals testing because of its rapid, precise and relevant information than testing with animals Living organisms are consist extremely complex symmetry made up of thousands of genes, proteins, nucleic acids, and so many organic compounds, inorganic compounds etc. This are organized to perform the biological activities. This complexity creates difficult to determine the interaction between individual components of this complex structure. In vitro techniques simplify the complexity of systems under study $[22,23]$.

In the field of pharmacology drug testing can easily and safely do with aid of in-vitro technique. We can collect several tissues of several copies and studying their toxicities and their mechanism of action. In vitro test for genetic toxicology can replace the animal tests. To find a particular adverse effect of a drug can most reliably detected by in vitro technique. In vitro tests mostly proceed through two phases or steps, first one include a series of individual tasks and $2^{\text {nd }}$ phase consist of more investigation in the previous phase [24].

\section{Alternative and Bacterial sequencing techniques}

Pedro-Miramontes, a mathematician from a Mexican University, presented the report on DNA and RNA restraints on physiological, chemical and cytological information carried out entirely in a computer. Nowadays, this method is widely used in studies which predict how the body interacts with pathogens. Variety of in-silico techniques is bacterial sequencing technique, molecular modeling and whole cell stimulators [25]. Numerous Insilco methods were established as an alternative to in-vitro methods for identifying bacteria, which can help in sequencing DNA 
and RNA of bacteria. The frequently used method is PCR. Polymerase chain reaction takes single / a small number of copies of DNA and increases it in crossways by producing additional copies of specific sequence of DNA. It is useful to bear a resemblance to distinguish the bacteria [26]. Computerization and information technology based models

Computerization and information technology can support to make the numerous simple principles of Biosciences. Computerized simulation models are used to predict the various potential biotic and toxicological effects of chemical and possible disease or pathological conditions without animal model use or reduction in the amount of used animals. One example is to know about the binding site receptors of any drug or chemical agent used in in-vivo studies. The software like computer assisted drug design (CADD) is widely used to predict the receptors and binding sites for the specific prospective drug and chemicals molecule [27, 28].

\section{Cells and tissue culture}

Study involves the use of an in-vitro model like cell culture and tissue culture which comprises the growth of cells and tissue in the laboratory can be significant substitutions for the animal model experimentations. The cells and tissues from various organ systems of the body like liver, kidney, brain, skin etc. removed from animals and can preserved, invitro cultures of different animal species as well as human cell lines include their separation from developing monolayer over the natural and designed surface of culture places e.g. culture plates and used flasks in tissue culture experimentation. Numerous categories of the cell and tissue culture are being used for several biological determinations [29, 30].

\section{Alternate type of animal models and organisms}

The animal-ethics and related issues have pretended considerable restraints over the experimental usage of the higher animal models like, cattle's, small ruminants dogs, cats, monkeys, guinea pigs, rabbits and rats etc. Prokaryotic living organisms like E.coli and other bacterial models for molecular and genetics researches are now a day encouraged doing the biological research $[31,32]$. Bacillus subtilis- model for cellular differentiation, protists- Dictyostelium discoideum model for molecular and genetic studies, fungiNeurospora crassa model for bio technological genetic aspects and circardian rhythm and the animals like Denio rerio, commonly known as zebra fish, a small fresh water fish with an appropriate length of $2-4 \mathrm{~cm}$ can be encouraged to use as lower animal models for many scientific aspects of different research projects. Invertebrate are widely used animal models as a substitute for laboratory animals and higher animals. These animals had been used for the study of various disease and metabolic conditions like endocrine disfunctions, histopathology of brain and nerves, other conditions like memory dysfunction, muscle dystrophy, skin-wound healing and tropical skin disorders etc. [33]. The other organisms like Fruit fly are the one of the furthermost and extensively used invertebrate $\mathrm{s}$ in the biosciences research. A big percentage of genes involved in human disease are believed to have a well-designed homology to the flies like D. Melanogaster requires [29].

\section{Microorganisms}

The other microorganisms like brewing yeasts, saccharomyces cervisiae are of furthermost importance model creature due to the above-mentioned properties of speedy growth of ease in replica plating, mutant isolation and well-demarcated genetic system made of highly handy makeover $[34,35]$. To develop an appropriate information sources on alternatives in Bioscience research and education, information of the following organisms support the their use as alternate animal models in biology research and higher education will provide relevant information on 
the accessibility of many alternate research models in future science[3]. The organisations like European Resource Centre for alternatives in higher research and education (EURCA) are actively promoting the use of substitutions to using higher animal models in Bioscience research and higher education. Cinematographic substitutions also can be considered as a useful addition to the use of animals in classroom teaching [36, 37].

\section{Conclusions}

Animals are used so far for teaching purpose since many decades especially in surgical and anatomic procedures. But in terms of animal welfare, it is necessary to be modernized using 3 R's principles of replacement, reduction, and refinement in the use of animals in experiment. It is one of the righteous thought to seek avenues to implement minimization of animal use in teaching purpose. It is also pointed by educators at national and institutional level to reduce use of use if animals in undergraduate as well as post graduate curriculum. It is necessary to go by realistic approach to implement regarding welfare of animals by students and to develop compassion towards animas.

\section{Authors' contributions}

Conceived and designed the experiments: NA Ravindran, K Safdar \& MS Khan, Performed the experiments/ review materials: $S$ Pullikkunnummal, BFF Manzil, MK Ganesh \& SY Ramappa, Analyzed the data/Editing: S Ullah, A Javaid, NA Ravindran, Contributed reagents/ materials/ analysis tools: $S$ Ullah \& A Javaid, Wrote the paper: $S$ Pullikkunnummal, BFF Manzil, MK Ganesh, SY Ramappa \& MS Khan.

\section{References}

1. Yoon M, Campbell JL, Andersen ME \& Clewell HJ (2012). Quantitative in vitro to in vivo extrapolation of cell-based toxicity assay results. Critical rev in toxic 42: 633-652.

2. Reznick RK \& MacRae H (2006). Teaching surgical skills-changes in the wind. New England J Med 355: 26642669.

3. Vander Valk J, Dewhurst D, Hughes I, Atkinson J, Balcombe J, Braum $\mathrm{H}$, Gabrielson K, Gruber F, Miles J \& Nab J (1999). Alternatives to the use of animals in higher education.

4. Daneshian M, Akbarsha MA, Blaauboer B, Caloni F, Cosson P, Curren R, Goldberg A, Gruber F, Ohl F \& Pfaller W (2011). A framework program for the teaching of alternative methods (replacement, reduction, refinement) to animal experimentation. Alternatives to animal experimentation: ALTEX 28: 341352.

5. Akbarsha MA, Zeeshan M \& Meenekumari K (2013). Alternatives to animals in education, research and risk assessment: An overview with special reference to Indian context. ALTEX Proc 2: 5-19.

6. Guhad F (2005). Introduction to the 3Rs (refinement, reduction and replacement). J Amr Assoc Lab Anim Sci 44:58-59.

7. Kilkenny C, Browne WJ, Cuthill IC, Emerson M \& Altman DG (2010). Improving bioscience research reporting: the ARRIVE guidelines for reporting animal research. PLoS biology 8, e1000412.

8. Council NR (2010). Guide for the care and use of laboratory animals.National Academies Press.

9. Ozgok Y (2015). Planning and designing of an ideal animal laboratory set up for surgical training. Current Opin Urolo 25: 175-181.

10. Olsson AS, Robinson P, Pritchett K \& Sandøe P (2002). Animal research ethics. Hau J \& Van Hoosier Jr GL, Handbook of Lab Anim Sci 1: 13-31.

11. Balls M (1994). Replacement of animal procedures: alternatives in research, education and testing. Lab Anim 28: 193211. 
12. Festing $\mathrm{S} \&$ Wilkinson $\mathrm{R}$ (2007). The ethics of animal research. EMBO reports 8: 526-530.

13. Martinsen S \& Jukes N (2005). Towards a humane veterinary education. $J$ Vet Med Edu 32: 454-460.

14. Laurillard D (2013). Rethinking university teaching: A conversational framework for the effective use of learning technologies.(Routledge).

15. Langley G (1991). Animals in science education-ethics and alternatives. J Bio Edu 25: 274-279.

16. Taylor PW (2011). Respect for nature: A theory of environmental ethics.(Princeton University Press).

17. Miller RA \& Nadon NL (2000). Principles of animal use for gerontological research. The Journals of Gerontology Series A: Biologic Sci Medic Sci 55: 117-123.

18. Young RJ (2013). Environmental enrichment for captive animals.(John Wiley \& Sons).

19. Patronek GJ \& Rauch A (2007). Systematic review of comparative studies examining alternatives to the harmful use of animals in biomedical education. $J$ Anim Vet Med Assoc 23: 37-43.

20. Valliyate M, Robinson N \& Goodman J (2012). Current concepts in simulation and other alternatives for veterinary education: a review. Vet Medi 57.

21. Hart LA, Wood MW \& Weng HY (2005). Mainstreaming alternatives in veterinary medical education: resource development and curricular reform. $J$ Vet Med Edu 32: 473-480.

22. McClements DJ \& Li Y (2010). Review of in vitro digestion models for rapid screening of emulsion-based systems. Food \& Function 1: 32-59.

23. Haycock JW (2011). 3D cell culture: a review of current approaches and techniques. 3D cell culture: methods and protocols 1-15.
24. Huh D, Hamilton GA \& Ingber DE (2011). From 3D cell culture to organson-chips. Trends Cell Biol 21: 745-754.

25. Vanjari S, Chimandare N \& Gandhi S (2012). A review on in silico approach in pharmacology. Adv Res Pharm Biol 2: 129-141.

26. Bornholt J, Lopez R, Carmean DM, Ceze L, Seelig G \& Strauss K (2016). A DNAbased archival storage system. ACM SIGOPS Operating Systems Rev 50: 637649.

27. Sliwoski G, Kothiwale S, Meiler J \& Lowe EW (2014). Computational methods in drug discovery. Pharma Rev 66: 334-395.

28. Balcombe $\mathbf{J}$ (2000). The use of animals in higher education: problems, alternatives, \& recommendations, The Humane Society Press, United States, Washington, DC.

29. Doke SK \& Dhawale SC (2015). Alternatives to animal testing: A review. Saudi Pharma J 23: 223-229.

30. Erkekoglu P, Giray BK \& Basaran N (2011). 3R principle and alternative toxicity testing methods. Fabad J Pharm Sci 36: 101-117.

31. Baba T, Ara T, Hasegawa M, Takai Y, Okumura Y, Baba M, Datsenko KA, Tomita M, Wanner BL \& Mori H (2006). Construction of Escherichia coli K-12 inframe, single-gene knockout mutants: the Keio collection. Molecular systems biology 2: 1-11.

32. Nevalainen T, Blom H, Guaitani A, Hardy P, Howard B \& Vergara P (2002). FELASA recommendations for the accreditation of laboratory animal science education and training: Report of the Federation of European Laboratory Animal Science Associations Working Group on Accreditation of Laboratory Animal Science Education and Training. Lab anim 36: 73-377. 
33. Wilson-Sanders SE (2011). Invertebrate models for biomedical research, testing, and education. ILRI 52: 126-152.

34. Kurtzman C, Fell JW \& Boekhout T (2011). The yeasts: a taxonomic study. Elsevier eBook ISBN: 9780080931272.

35. Rasmussen LM, Robinson RA \& Johnston GR (2003). A pedagogically sound innovative and humane plan for veterinary medical education. From Guinea Pig to Computer Mouse:
Alternative Methods for a Progressive Humane Education, 2nd ed, N Jukes and M Chiuia, pp125-133, Int NICHE, UK.

36. Allchin D (2012). The Minnesota case study collection: New historical inquiry case studies for nature of science education. Sci \& Edu 21:1263-1281.

37. Oakley J (2012). Science teachers and the dissection debate: perspectives on animal dissection and alternatives. Int J Envirn \& Sci Edu 7:253-267. 